\title{
MAGNA and BLANQ Series: Two Yellow-fleshed and Three White- fleshed Nectarines
}

Carolina Font i Forcada, Gemma Reig, and Christian Fontich

Institute of Agrifood Research and Technology, Fruitcentre, Lleida, Spain

Ignasi Batlle

Institute of Agrifood Research and Technology, Mas Bové, Tarragona, Spain

\section{Simó Alegre}

Institute of Agrifood Research and Technology, Fruitcentre, Lleida, Spain

\section{Celia M. Cantín}

Institute of Agrifood Research and Technology, Fruitcentre, Lleida, Spain; Aragonese Agency for Research and Development Foundation (ARAID), Zaragoza, Spain; and Center for Research and Agrifood Technology of Aragon (CITA), Zaragoza, Spain

\section{Iban Eduardo}

Institute of Agrifood Research and Technology, Fruitcentre, Lleida, Spain; and Center for Research in Agricultural Genomics (CRAG)-Superior Council of Scientific Investigations (CSIC)-Institute of Agrifood Research and Technology (IRTA)-Autonomous University of Barcelona (UAB)-University of Barcelona (UB), Campus UAB, Barcelona, Spain

\section{Joaquim Carbó}

Institute of Agrifood Research and Technology, Mas Badia, Girona, Spain

Arsène Maillard and Laurence Maillard

Agro Séléctions Fruits (ASF), La Prade de Mousseillous, Elne, France

\section{Joan Bonany}

Institute of Agrifood Research and Technology, Mas Badia, Girona, Spain

Additional index words. color, fruit quality, Prunus persica, ripening, yield

The continuous release of new nectarine [Prunus persica (L.) Batsch] cultivars by breeders from around the world, together with consistent improvements in orchard management strategies by growers, commercial interest in the production of fruit fresh consumption, and the introduction of new cultivars from Spanish scion nectarine breeding programs have positioned Spain as the preeminent worldwide nectarine exporter and currently the largest European producer

Received for publication 30 Mar. 2021. Accepted for publication 11 June 2021.

Published online 20 August 2021.

This research was supported by the Research Centers of Catalonia (CERCA) Program/Generalitat of Catalonia. We also thank FruitFutur (Spain) for their support of the breeding program and FruitFutur members for their help during the whole trialing process carried out at Gimenells. C.F.F. and G.R. contributed equally.

C.F.F. is the corresponding author. E-mail: carolina.font@irta.cat.

This is an open access article distributed under the CC BY-NC-ND license (https://creativecommons. org/licenses/by-nc-nd/4.0/).
[Ministry of Agriculture, Food and Environment (MAPAMA), 2021]. In Spain, the main nectarine-producing area is the Ebro Valley that accounts for more than $60 \%$ of the total Spanish peach and nectarine production (MAPAMA, 2021).

Among all type fruits (nectarine, peach, flat peach, and flat nectarine), nectarine is the most produced in the last 15 years in Spain. The most significant change in the Spanish nectarine industry in recent decades has been the development and introduction of precocious new cultivars which generally have a full red overcolor, good size, predominantly sweet taste, and slow-melting flesh. This change started two decades ago, with the introduction of the yellow-fleshed nectarine 'Big Top' (Zaiger Genetics Inc., Modesto, CA), which has been widely accepted by European retailers and consumers, offering significant advantages in harvest and postharvest management and fruit quality characteristics (Reig et al., 2017). 'Big Top' continues to be the midseason (July) reference nectarine cultivar in Europe for fresh consumption, with $95 \%$ of the cultivars that are currently planted belonging to this fruit typology. However, some of these new cultivars are not well-adapted to Spanish environmental conditions (Font i Forcada et al., 2014, 2019)

The Agro Séléctions Fruits (ASF)-Institute of Agrifood Research and Technology (IRTA) scion nectarine breeding program started in 2004 (Batlle et al., 2012) aiming to develop high-quality nectarine cultivars well-adapted to the typical edaphoclimatic conditions of Ebro Valley and other similar hot climates, covering full harvesting period from June to September (Cantín et al., 2017). Trees were selected that produce high-quality fruits at both harvest and after cold storage, with the ultimate objective of satisfying consumers. Therefore, as a result of the continued effort from the ASF-IRTA nectarine breeding program, the initial MAGNA and BLANQ series of yellow- and white-fleshed nectarine cultivars, respectively, have been recently released.

These five new nectarine cultivars will supply high-quality, firm, attractive, and sweet fruit over 12 weeks, from mid-June until mid-September, in the medium chilling zone of Ebro Valley and similar areas (moderate temperatures during winter, periods of fog during wintertime, summer temperatures of over $30^{\circ} \mathrm{C}$, and yearly accumulated annual rainfall of $300-400 \mathrm{~mm}$ )

\section{Origin}

Regarding MAGNA nectarines, 'MAGNA 2901' was a seedling from 'Redpearl' $\times$ ASF 01.23.15.02 NJ, and 'MAGNA 3701' was from 01.16.13.02 $\mathrm{NJ} \times$ ASF 01.24.93.02 NJ. For BLANQ nectarines, 'BLANQ 2601' was a seedling from ASF 11.01.290.94 NB $\times$ ASF 01.01.02.00 NJ, 'BLANQ 3001' was from ASF 01.14.77.01 NB $\times$ ASF 01.07.43.01 NJ, and 'BLANQ 3301' was from 'JMD698 $\mathrm{NB}^{\prime} \times$ 01.24.49.02 NJ.

\section{Description}

Phenotypic and morphologic descriptors (tree, flower, leaf, and fruit traits) developed by the International Union for the Protection of New Varieties and Plants (UPOV, 2010) and the Community Plant Variety Office (CPVO, 2015) were used to describe the MAGNA and BLANQ nectarine series (Supplemental Table 1).

The MAGNA nectarine series (yellowfleshed) generally have spreading growth habit, although 'MAGNA 3701' tends to have some upright branches. Under Gimenells climatic conditions, full bloom occurs during March, and harvesting between July and September. Both selections exhibit sparse density of flower buds (Table 1).

The BLANQ nectarine series (whitefleshed) have spreading growth habit, although 'BLANQ 2601' and 'BLANQ 3001' tend to have some upright branches. Under our climatic conditions, full bloom occurs during March, and harvesting between June and August. They all have showy flowers, with the exceptions of 'BLANQ 2601', which has 
Table 1. Comparison of several characteristics of the MAGNA and BLANQ nectarine series with the commercial standard 'Big Top' and 'Garcica' trialed at the Institute of Agrifood Research and Technology, Spain.

\begin{tabular}{|c|c|c|c|c|c|c|c|}
\hline Trait & MAGNA 2901 & MAGNA 3701 & BLANQ 2601 & BLANQ 3001 & BLANQ 3301 & Big Top $^{z}$ & Garcica $^{z}$ \\
\hline$\overline{\text { Flowering period }}$ & 7-17 Mar. & 8-18 Mar. & 2-16 Mar. & 8-15 Mar. & 7-17 Mar. & 4-14 Mar. & 5-22 Mar. \\
\hline Harvest period & 17-31 July & 8-24 Sept. & 20 June-5 July & 21 July-8 Aug. & 22 Aug. -7 Sept. & 25 June-10 July & 27 June-19 July \\
\hline Yield $(\mathrm{kg} /$ tree $)$ & 78.6 & 91.9 & 44.3 & 61.5 & 58.1 & 30.5 & 32.5 \\
\hline Soluble solids ( ${ }^{\circ}$ Brix $)$ & 12.9 & 12.1 & 11.6 & 12.0 & 12.2 & 11.3 & 11.7 \\
\hline Acidity $\left(\mathrm{g} \cdot \mathrm{L}^{-1}\right.$ malic aid $)$ & 5.1 & 4.3 & 5.3 & 5.1 & 4.6 & 5.0 & 5.4 \\
\hline Red blush (\%) & $80-100$ & $50-70$ & $90-100$ & $70-90$ & $70-80$ & $90-95$ & $90-95$ \\
\hline Dominant caliber $(\mathrm{mm})$ & $70-75$ & $80-85$ & $70-75$ & $75-80$ & $75-80$ & $75-80$ & $75-80$ \\
\hline
\end{tabular}

${ }^{\mathrm{z} \text { Reference cultivar. }}$

campanulate flowers, and 'BLANQ 3001' and 'BLANQ 3301' present sparse density of flower buds (Table 1).

For both nectarine series, there is no need for thinning at full bloom, as fruit thinning will effectively optimize fruit size.

\section{Performance}

All five cultivars were originally selected as seedlings grown at selection plots and then grafted onto 'Cadaman' rootstock after selection, being the fifth most used rootstock in Ebro Valley's (Reig et al., 2020). Three or four trees of each selection were placed at an experimental orchard of the Institute of Agrifood Research and Technology, Gimenells, Spain (lat. 41 ${ }^{\circ} 39^{\prime} 18.77 \mathrm{~N}$, long. $0^{\circ} 23^{\prime} 31.41$ $\mathrm{E}$; elevation, $230 \mathrm{~m}$ ). Trees were trained to an open or Catalan vase system (Iglesias, 2019), spaced at $5 \times 3 \mathrm{~m}$. Each year, the trees received integrated pest management. The quantitative data presented summarizes the average values for 9 years collected on fullsize trees.

Maturity time. Among the MAGNA nectarine series, 'MAGNA 2901' is a midseason cultivar, whereas 'MAGNA 3701' is a lateseason cultivar (Table 1). Regarding the BLANQ nectarine series, 'BLANQ 2601' is an early-season cultivar, whereas both 'BLANQ 3001' and 'BLANQ 3301' are midseason cultivars.

Yield. The trees were harvested in two to three picks separated by 3 to $5 \mathrm{~d}$. After harvesting, the whole production of each controlled tree was graded for fruit size and weight using a commercial electronic fruit grader (MAF RODA, Iberica, Spain). Total yield per tree, average fruit weight, and total number of fruits per fruit size were then calculated for each pick. Under our conditions, all five nectarine cultivars stood out for their high productivity and good fruit size, regardless of their harvest season (Table 1).

Fruit quality. Fruits of five cultivars were examined at commercial maturity, using samples of 12 fruits per cultivar. All cultivars were generally found to be sweeter than current commercial cultivars within each harvest period, juicy, aromatic, and crunchy (Table 1, Supplemental Table 1). All of them are nearly $100 \%$ red skin colored, except for 'MAGNA 3701' (Supplemental Fig. 1), which could be considered a bi-color nectarine. The fruits are generally round shape without a mucron tip. The presence of skin lenticels is visible in 'BLANQ 3301' (Supplemental Fig. 1), weakly visible in 'MAGNA 2901', and low in the other cultivars. It should be noted that hot climates such as Ebro Valley's are conducive to the development of lenticels on fruit skin. In addition, this defect is related to wood aging. However, these two issues do not seem to affect 'MAGNA 2901' fruits.

Postharvest performance. Thirty fruits from the first harvest of each cultivar were kept at $0.5^{\circ} \mathrm{C}$ for $30 \mathrm{~d}$ and then for 2 additional days at $20^{\circ} \mathrm{C}$. Each fruit was then scored based on a visual rating of chillinginjury symptoms (mealiness and internal browning). Each cultivar was then classified as having good, moderate, or poor long-term performance. The yellow- and white-fleshed nectarines 'MAGNA 3701' and 'BLANQ 2601', and 'BLANQ 3301', respectively, were the least susceptible to chilling injury after long periods of cold storage (Supplemental Table 1).

\section{Availability}

The cultivars are protected by the Community Plant Variety Office, with the following registration numbers: 20113179 for 'MAGNA 2901', 20122741 for 'MAGNA 3701', 20132984 for 'BLANQ 2601', 20122738 for 'BLANQ 3001', and 20113183 for 'BLANQ 3301'. Virus-free plants are available from nurseries authorized by the Institute of Agrifood Research and Technology (IRTA, Spain). The plant material was laboratory-tested and showed negative results for Agrobacterium tumefaciens [via reverse transcription-polymerase chain reaction (RT-PCR)], Apple chlorotic leaf spot virus [via enzyme-linked immunosorbent assay (ELISA)], Candidatus Phytoplasma prunorum (via RT-PCR), Peach latent mosaic viroid (via molecular hybridization), Plum pox virus (via ELISA), Prune dwarf virus (via ELISA), Prunus Necrotic ring spot virus (via ELISA), Xanthomonas arboricola pv. pruni (via RT-PCR), and Xylella fastidiosa (via RT-PCR).

\section{Literature Cited}

Batlle, I., C. Fontich, L. Lozano, I. Iglesias, G. Reig, S. Alegre, G. Echeverría, F. de Herralde, E. Claveria, R. Dolcet-Sanjuan, J. Carbó, J. Bonany, A. Maillard, and L. Maillard. 2012. The peach breeding programme IRTA-ASF: Aiming for high fruit quality. Acta Hort. 940:75-78, doi: 10.17660/ActaHortic.2012.940.8.

Cantín, C.M., F. Fontich, I. Batlle, I. Iglesias, R. Dolcet-Sanjuan, S. Alegre, J. Carbó, J. Bonany, A. Maillard, and L. Maillard. 2017. The joint IRTA-ASF peach breeding program: Outstanding quality fruit adapted to the Mediterranean conditions. Acta Hort. 1172:151-154, doi: 10.17660/ActaHortic. 2017.1172.29

Community Plant Variety Office. 2015. Protocol for tests on distinctness, uniformity and stability. TP/053/2 Rev.

Font i Forcada, C., T.M. Gradziel, Y. Gogorcena, and M.A. Moreno. 2014. Phenotypic diversity among local Spanish and foreign peach and nectarine [Prunus persica (L.) Batsch] accessions. Euphytica 197:261-277, doi: 10.1007/ s10681-014-1065-9.

Font i Forcada, C., G. Reig, R. Giménez, P. Mignard, L. Mestre, and M.A. Moreno. 2019. Sugars and organic acids profile and antioxidant compounds of nectarine fruits influenced by different rootstocks. Scientia Hort. 248:145-153, doi: 10.1016/j.scienta.2018.12.010

Iglesias, I. 2019. Sistemas de plantación 2D: Una novedad en almendro, una realidad en frutales: Hacia una alta eficiencia. Rev. Frutic. 67:23-44.

International Union for the Protection of New Varieties of Plants. 2010. Guidelines for the conduct of tests for distinctness, uniformity and stability to peach [Prunus persica (L.) Batsch]. TG/53/7 Rev. International Union for the Protection of New Varieties of Plants, Geneva, Switzerland. 21 June 2021. <https://www. upov.int/edocs/tgdocs/en/tg053.pdf >.

Ministry of Agriculture, Food and Environment (MAPAMA). 2021. Mar. 2021. <https://www. mapama.gob.es/es/>.

Reig, G., A. Alegre, C. Cantín, F. Gatius, and I. Iglesias. 2017. Tree ripening and postharvest firmness loss of eleven commercial nectarine cultivars under Mediterranean conditions. Scientia Hort. 219:335-343, doi: 10.1016/j.scienta.2017.03.001.

Reig, G., X. Garanto, N. Mas, and I. Iglesias. 2020. Long-term agronomical performance and iron chlorosis susceptibility of several Prunus rootstocks under loamy and calcareous soil conditions. Scientia Hort. 262:109035, doi: 10.1016/j.scienta.2019.109035. 


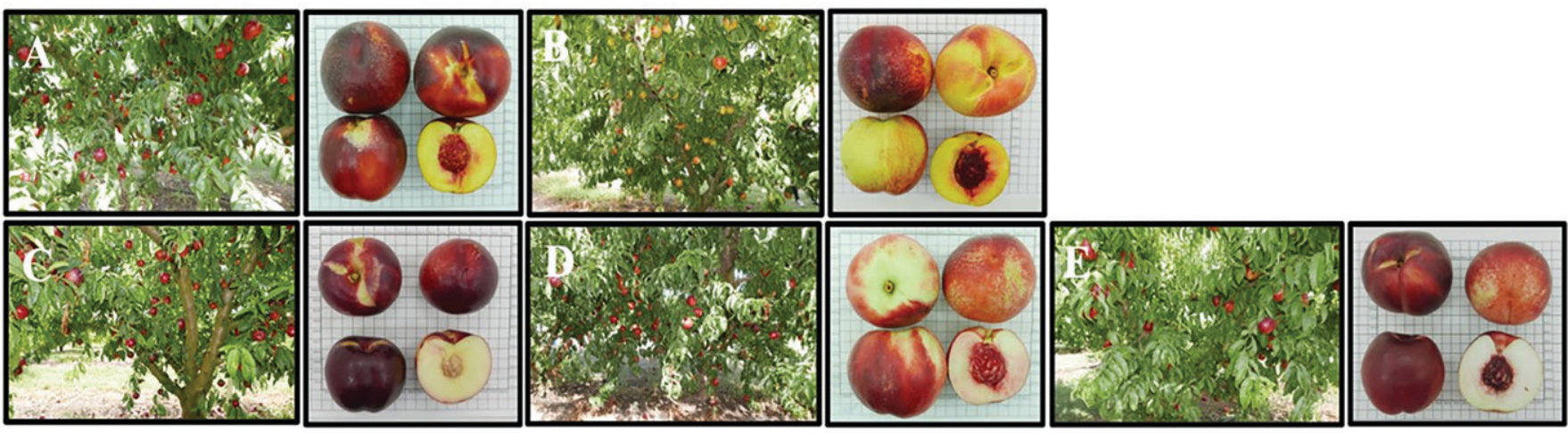

Supplemental Fig. 1. Typical fruit appearance of commercially ripe MAGNA and BLANQ nectarine series: (A) 'MAGNA 2901', (B) 'MAGNA 3701', (C) 'BLANQ 2601', (D) 'BLANQ 3001', and (E) 'BLANQ 3301'.

Supplemental Table 1. Comparison of several characteristics of the MAGNA and BLANQ nectarine series trialed at the Institute of Agrifood Research and Technology, Gimenells, Lleida, Spain.

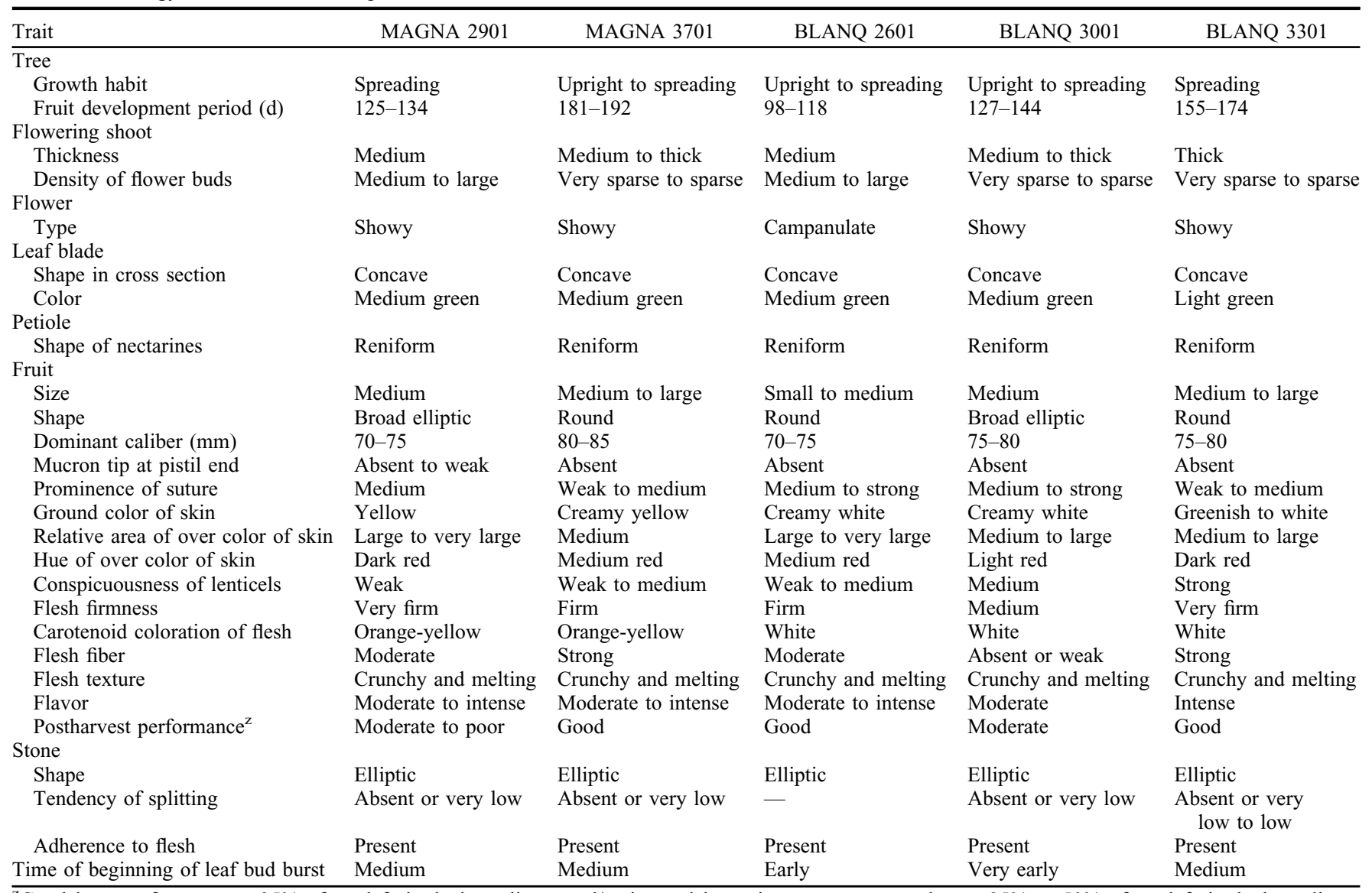

${ }^{\mathrm{z}}$ Good long performance, $<25 \%$ of total fruits had mealiness and/or internal browning symptoms; moderate, $25 \%$ to $50 \%$ of total fruits had mealiness and/or internal browning symptoms; and poor, $>50 \%$ of total fruits had mealiness and/or internal browning symptoms. 